\title{
Selective-placement burial of drilling fluids: Effects on soil properties, buffalograss and fourwing salt- bush after 4 years
}

\author{
MARK L. MCFARLAND, DARRELL N. UECKERT, FRANK M. HONS AND STEVE \\ HARTMANN
}

Authors are with the Texas Natural Resource Conservation Commission, Austin 78711; professor, Texas Agricultural Experiment Station, San Angelo 76901; professor, Soil and Crop Sciences Dep., Texas A\&M University, College Station 77843; Manager, University Lands, The University of Texas System, Midland 79702.

\begin{abstract}
A field study was established in 1986 to evaluate selectiveplacement burial as an alternative technique for on-site disposal of drilling fluids in arid and semiarid areas. Soluble salt and heavy metal migration in the soil, and establishment, yield and chemical composition of fourwing saltbush (Atriplex canescens (Pursh) Nutt.) and buffalograss (Buchloe dactyloides (Nutt.) Engelm.) were determined 44 months after simulated reserve pits were constructed to provide burial depths of 30,90 (with and without a $30-\mathrm{cm}$ thick, coarse limestone capillary barrier), and $150 \mathrm{~cm}$, with sequential replacement of stockpiled subsoil and topsoil. Soluble salt concentrations increased most significantly in the 30-cm zone immediately above buried drilling fluids, regardless of treatment. Upward salt movement was greatest in the 90 - and $150-\mathrm{cm}$ treatments, with significant increases in Electrical Conductivity (EC) and Exchangeable Sodium Percentage (ESP) values observed as much as 60 and $30 \mathrm{~cm}$ above buried drilling fluid, respectively. Capillary barriers reduced the extent of upward salt migration, but had little effect in soil zones immediately overlying the drilling fluid. There was no evidence of upward migration of $\mathrm{Ba}, \mathrm{Cr}, \mathrm{Cu}, \mathrm{Ni}$, or $\mathrm{Zn}$ from buried drilling fluids into overlying soil, but concentrations of $\mathrm{Cu}$ and $Z_{n}$ were greater in saltbush stems grown on plots with buried drilling fluids on 1 site. Fourwing saltbush survival averaged 92 to $100 \%$ and was not affected by depth of drilling fluid burial. Significant reductions in saltbush canopy cover and yield on the 30-cm burial treatment were observed on 1 study site. Elevated Na concentrations in aboveground tissue of both species in the 30-cm burial treatment on 1 site did not adversely affect survival or plant growth. Differences between study sites in the extent of upward salt movement in the soil and in plant response were attributed to differences in soil clay type and content.
\end{abstract}

Key words: salinity, sodium, hazardous waste, heavy metals, Atriplex canescenes, Buchloe dactyloides

Onsite, surface disposal of drilling fluids used in petroleum and

Approved by the Director, the Texas Agricultural Experiment Station as TA-31271. Manuscript accepted 9 Feb. 1994. natural gas exploration is a common practice in arid and semiarid regions of the southwestern United States, even though severe and permanent soil contamination occurs (McFarland et al. 1987). Selective-placement burial, a technique developed for coal mine reclamation, presents an alternative to surface disposal in which drilling fluids are worked, stored, dried, and eventually buried at a predetermined depth below the soil surface. In this process, soil contamination is minimized, the waste volume is reduced, and the potential for revegetation is enhanced.

Field research was initiated in autumn 1985 to evaluate the effects of selective-placement burial of drilling fluids on soil chemical properties and on establishment, growth, and chemical composition of 2 species used for revegetation. Results reported after 20 months showed that soluble salts had migrated upward 15 to $30 \mathrm{~cm}$ into overlying soil and capillary barriers of coarse limestone were only partially effective in reducing salt movement (McFarland et al. 1992a). There was no evidence of upward migration of heavy metals $(\mathrm{Ba}, \mathrm{Cr}$, $\mathrm{Cu}, \mathrm{Ni}, \mathrm{Zn}$ ) from the buried drilling fluids. Survival and growth of fourwing saltbush (Atriplex canescens (Pursh) Nutt.) and buffalograss (Buchloe dactyloides (Nutt.) Engelm.) were not affected by depth of drilling fluid burial 17 months after planting, although significant increases in $\mathrm{Na}$ and $\mathrm{K}$ concentrations in both species at $\mathrm{I}$ location indicated plant uptake of drilling fluid constituents occurred where burial depth was $30 \mathrm{~cm}$ (McFarland et al. 1992b). A more significant finding was evidence of elevated $\mathrm{Zn}$ concentrations in fourwing saltbush leaf and stem tissue on plots where drilling fluid was buried 30 or $90 \mathrm{~cm}$. This paper presents a comparative analysis of treatment effects on soils and plant growth based on data collected after 4 growing seasons (44 months after study initiation).

\section{Materials and Methods}

The study was established in 1985-86 in the northwestern Edwards Plateau of Texas. Study sites were $10 \mathrm{~km}$ north of Big Lake in Reagan County (Weatherby site) and $34 \mathrm{~km}$ southwest of Mertzon it Schleicher County (Mertz site). Reagan County is semiarid with an average annual rainfall of $430 \mathrm{~mm}$ and a mean annual lake evaporation of $1,800 \mathrm{~mm}$ (Blum 1977). The study area was on a level, upland site on a Reagan clay loam (fine-silty, mixed, thermic, Ustollic Calciorthid). The average annual rainfall in Schleicher county is $\mathbf{4 6 0}$ $\mathrm{mm}$ and the mean annual lake evaporation is $1.780 \mathrm{~mm}$ (Wiedenfeld 1980). The study site was on a flat valley floor above the overflow 
zone on an Angelo clay loam (fine-silty, mixed, thermic, Aridic Calciustoll).

Fifteen, 9.1 - by $9.1-\mathrm{m}$ simulated reserve pits separated by $9.1-\mathrm{m}$ buffers were constructed at each location in August 1985 using a bulldozer. Treatments included burial of drilling fluid at 30,90 , or $150 \mathrm{~cm}$, burial at $90 \mathrm{~cm}$ with a $30-\mathrm{cm}$ capillary barrier of coarse limestone (Edwards Group) immediately above the drilling fluid, and an undisturbed control from which existing vegetation was cleared with the dozer blade. Topsoil and subsoil were removed and stockpiled separately during pit construction. Spent fluids from 2 drilling locations near each study site were transported to the sites in dump trucks in September 1985. Equal volumes of about $25 \mathrm{~m}^{3}$ of drilling fluid were placed as a uniform $30-\mathrm{cm}$ layer into each pit, allowed to dry, and then covered by sequential replacement of subsoil and topsoil in January 1986. Experimental design was a randomized complete block arranged as a split plot with 3 replications. Replications were blocked by drilling fluid source.

The study sites were fenced to exclude livestock and lagomorphs, and grass and shrub seedlings were planted in spring 1986. Each reserve pit plot was divided into two, 4.6- by $9.1-\mathrm{m}$ subplots. Fourwing saltbush, a native, evergreen, halophytic shrub, and "Texoka" buffalograss, a native, perennial, warm-season shortgrass, were used to evaluate the effects of plant material on contaminant migration and as biological indicators to assay plant response to possible upward migration of contaminants or root penetration of buried waste. Forty seedlings of buffalograss were transplanted on $1-\mathrm{m}$ centers on 1 subplot of each pit. Seedlings were grown in a greenhouse in an equal-volume peat moss/vermiculite/ soil mixture in 4 - by 5 - by $18-\mathrm{cm}$ polyethylene containers and were 5 months old at transplanting. Twenty-four, 1-year-old rooted stem-cuttings of fourwing saltbush were transplanted on $1.5-\mathrm{m}$ centers on the other subplot. Stemcuttings were taken from mature plants which were established in 1982 on a highly saline reserve pit $\left(E C=90 \mathrm{dS} \mathrm{m}^{-1}, \mathrm{SAR}=46\right)$ near Big Lake, Texas. Stem-cuttings were rooted for about 2 weeks in a $1: 1$ (v:v) sand/vermiculite mixture using an intermittent misting system in a greenhouse, and then transferred to $4-$ by $5-$ by $18-\mathrm{cm}$ polyethylene containers filled with an equal-volume peat moss/vermiculite/soil mixture.

Results from analyses of soil samples collected 1,8 , and 20 months after the treatments were installed were reported previously (McFarland et al. 1992a). Data presented in this paper are from similar analyses conducted on samples collected after 44 months. Sampling trenches bisecting each plot were excavated to the soil/drilling fluid (or soil/limestone) interface using a backhoe in August 1989. Samples were collected from the pit wall in $30-\mathrm{cm}$ depth increments, with zones at the soil/drilling fluid and soil/air interfaces subdivided into $15-\mathrm{cm}$ increments. Composited soil samples from each subplot were air-dried and ground to pass a 2-mm sieve. Saturated paste extracts were obtained using the method described in USDA Handbook 60 (U.S. Salinity Laboratory Staff 1954). Total soluble salt concentrations were estimated by measuring the electrical conductivity (EC) of saturated paste extracts. Soluble $\mathrm{Na}^{+}$was measured by flame emission spectroscopy. Extractable $\mathrm{Na}^{+}$ was determined in soil extracts of neutral $1.0 \mathrm{M} \mathrm{NH} \mathrm{NAC}_{4} \mathrm{OA}$ wile exchangeable $\mathrm{Na}^{+}$was estimated as the difference of extractable $\mathrm{Na}^{+}$ minus water-soluble $\mathrm{Na}^{+}$and used to calculate the exchangeable sodium percentage (ESP) (U.S. Salinity Laboratory Staff 1954). Cation exchange capacity was determined by saturating soil samples with $1.0 M \mathrm{NaOAc}$, washing with ethanol, and replacing $\mathrm{Na}^{+}$with 1.0 $\mathrm{M} \mathrm{NH}_{4} \mathrm{OAc}$ (U.S. Salinity Laboratory Staff 1954).

Total concentrations of $\mathrm{Ba}, \mathrm{Cr}, \mathrm{Cu}, \mathrm{Ni}$ and $\mathrm{Zn}$ in soil were determined after $\mathrm{HNO}_{3}-\mathrm{HClO}_{4}$ digestion (Nelson et al. 1984) by inductively coupled argon plasma (ICP) emission spectroscopy. Simultaneous analysis of certified, standard soil samples from the
Canadian Certified Reference Materials Project was conducted to monitor accuracy.

Survival of fourwing saltbush was determined by counting the number of live plants in each subplot. Canopy cover of each species was estimated by measuring intercept along line transects (Canfield 1941) across both diagonals of each subplot. Canopy dimensions of fourwing saltbush were estimated by measuring 12 interior plants in each subplot. Canopy diameters were measured parallel with and perpendicular to the row. Shrub canopy heights were also measured. One or 2 fourwing saltbush plants from each subplot were harvested to $10 \mathrm{~cm}$ above ground level and oven-dried at $60^{\circ} \mathrm{C}$. The biomass and canopy height and diameter data were used to develop regression equations for estimating aboveground biomass (Peterson et al. 1987). Standing crops of buffalograss were estimated by harvesting to ground line in 10 , equidistantly-spaced, $0.25-\mathrm{m}^{2}$ quadrats in each subplot. Samples were oven-dried at $60^{\circ} \mathrm{C}$ to a constant weight and means calculated for each subplot.

Aboveground tissue samples were collected from 10 plants in each subplot, oven-dried at $60^{\circ} \mathrm{C}$, and ground to pass a $0.15-\mathrm{mm}$ sieve. Total concentrations of $\mathrm{Ca}, \mathrm{Mg}, \mathrm{Na}, \mathrm{K}, \mathrm{Ba}, \mathrm{Cr}, \mathrm{Cu}, \mathrm{Ni}$ and $\mathrm{Zn}$ were determined by ICP atomic emission spectroscopy after $\mathrm{HNO}_{3}$ $\mathrm{HClO}_{4}$ digestion of composited subsamples (Nelson et al. 1984).

Soil data were treated as a split-split plot with depth of burial the main-plot effect, plant species the subplot effect, and time (20 and 44 months) the sub-subplot effect. Among treatment comparisons of upward contaminant movement in the reconstructed soil profiles were facilitated by redefining the soil/drilling fluid (or soil/limestone) interface as the zero point. Treatment comparisons for EC and ESP data were made within each increment above this reference point. The data were subjected to analyses of variance $(P<0.05)$ and treatment means separated when appropriate using Fisher's least significant difference method (Gomez and Gomez 1984). Plant data were subjected to split plot analyses of variance $(P<0.05)$, where depth of burial was the main plot effect and plant species was the subplot effect. Means were separated by Duncan's new multiple range test when appropriate (Gomez and Gomez 1984).

\section{Results and Discussion}

\section{Soil Chemical Composition}

Physical and chemical characteristics of the soil profiles and drilling fluids were reported previously (McFarland et al. 1992a). Average electrical conductivities of the native soil profiles (0-203 $\mathrm{cm}$ ) at the Mertz and Weatherby sites were 1.0 (range 0.8-1.4) and 1.0 (range $0.7-1.3$ ) $\mathrm{dS} \mathrm{m}^{-1}$, respectively, and ESP values for the 2 sites averaged 0.6 (range $0.2-2.1$ ) and 0.8 (range $0.3-2.4$ ), respectively. Salt contamination of the drilling wastes was the predominant concern as evidenced by EC values of 155 to $185 \mathrm{dS} \mathrm{m}^{-1}$ and ESP values of 42 to 89 . Sodium and $\mathrm{C1}^{-}$were the dominant soluble ions, although $\mathrm{K}^{+}, \mathrm{Ca}^{+2}$, and $\mathrm{Mg}^{+2}$ concentrations were also much greater in drilling fluids than in native soils (McFarland et al. 1992a).

Rainfall at the Weatherby site during 1988 and 1989 totalled 454 and $281 \mathrm{~mm}$, respectively, compared to the long-term annual average of $430 \mathrm{~mm}$. Rainfall at the Mertz site totalled $514 \mathrm{~mm}$ in 1988 and $353 \mathrm{~mm}$ in 1989, compared to the long-term annual average of 460 $\mathrm{mm}$. Thus, in the year preceding this evaluation rainfall was about 35 and $23 \%$ less than the long-term averages for the sites. The 20 -month evaluation (McFarland et al. 1992a) occurred following a year of above-average rainfall in 1986 and average rainfall in 1987.

Salt movement into soil overlying drilling fluid was similar in subplots planted to fourwing saltbush and buffalograss, so the data were pooled for presentation. The time $x$ depth of burial interactions were significant for EC in the 0 to $15-, 15$ to 30 - and 30 to $60-\mathrm{cm}$ incre- 
Table 1. Average soil electrical conductivities at 5 increments above drilling fluid after 20 and 44 months as influenced by depth of burial.

\begin{tabular}{|c|c|c|c|c|}
\hline \multirow[b]{2}{*}{ Depth of burial } & \multicolumn{2}{|c|}{$\frac{\text { Mertz site }}{\text { Time (months) }}$} & \multicolumn{2}{|c|}{$\begin{array}{l}\text { Weatherby site } \\
\text { Time (months) }\end{array}$} \\
\hline & 20 & 44 & 20 & 44 \\
\hline$(\mathrm{cm})$ & $\cdots$ & $\begin{array}{l}\cdots \\
\text { rement al } \\
\cdots-(0 t\end{array}$ & ling flui & \\
\hline 30 & $4.4 \mathrm{a}^{*}$ & $24.2 \mathrm{bC}$ & 19.5 & 23.6 \\
\hline 90 & 8.1 & 14.5B & 21.1 & 21.0 \\
\hline 90 + barrier & 2.6 & $4.2 \mathrm{~A}$ & 10.6 & 16.4 \\
\hline \multirow[t]{2}{*}{150} & $9.2 \mathrm{a}$ & $21.0 \mathrm{bC}$ & 14.2 & 20.6 \\
\hline & \multicolumn{4}{|c|}{$\ldots \ldots$} \\
\hline 30 & 0.5 & $0.9 \mathrm{~A}$ & 4.3 & 10.0 \\
\hline 90 & $0.5 \mathrm{a}$ & $6.8 \mathrm{bB}$ & 5.2 & 37.3 \\
\hline $90+$ barrier & 0.5 & $1.3 \mathrm{~A}$ & 3.4 & 8.2 \\
\hline 150 & $1.4 \mathrm{a}$ & $14.8 \mathrm{bC}$ & 2.7 & 17.4 \\
\hline \multirow[t]{2}{*}{ Mean } & & & $3.9 a^{*}$ & $18.2 b$ \\
\hline & \multicolumn{4}{|c|}{$\ldots . . .(30$ to $60 \mathrm{~cm})-\ldots$} \\
\hline 90 & 0.4 & $0.6 \mathrm{~A}$ & $0.7 \mathrm{a}$ & $5.7 \mathrm{bB}$ \\
\hline 90 + barrier & 0.5 & $0.5 \mathrm{~A}$ & 1.0 & $1.6 \mathrm{~A}$ \\
\hline \multirow[t]{2}{*}{150} & $0.8 \mathrm{a}$ & $2.7 \mathrm{bB}$ & $0.9 \mathrm{a}$ & $4.2 \mathrm{bB}$ \\
\hline & \multicolumn{4}{|c|}{$\ldots \ldots$. 60 to $75 \mathrm{~cm}) \ldots$} \\
\hline 90 & 0.5 & 0.5 & 0.4 & 0.7 \\
\hline $90+$ barrier & 0.5 & 0.4 & 0.5 & 0.8 \\
\hline \multirow[t]{2}{*}{150} & 0.5 & 0.6 & 0.7 & 0.8 \\
\hline & \multicolumn{4}{|c|}{$\ldots \ldots$. (75 to $90 \mathrm{~cm})-\ldots .}$. \\
\hline 90 & 0.5 & 0.6 & 0.5 & 0.7 \\
\hline $90+$ barrier & 0.5 & 0.8 & 0.5 & 0.6 \\
\hline 150 & 0.4 & 0.7 & 0.9 & 0.7 \\
\hline
\end{tabular}

* For each location, means within a depth of burial and row followed by similar lower case letters and within an increment above drilling fluid and column followed by similar upper case letters are not significantly different by LSD $(P \leq 0.05)$.

ments above drilling fluids on the Mertz site (Table 1). In the 0 to $15-$ $\mathrm{cm}$ increment, EC values in the 30 - and $150-\mathrm{cm}$ burial treatments increased significantly over time, and a similar trend was observed in the $90-\mathrm{cm}$ treatment. The $90-\mathrm{cm}+$ barricr treatment significantly decreased the extent of upward salt migration compared to other burial treatments after 44 months. At 15 to $30 \mathrm{~cm}$ electrical conductivities in the 90 - and $150-\mathrm{cm}$ burial treatments increased significantly over time and were greater than those in the $30-\mathrm{cm}$ and $90-\mathrm{cm}+$ barrier treatments. Salt migration from drilling fluids into the 30 to 60 $\mathrm{cm}$ increment occurred only in the $150-\mathrm{cm}$ burial treatment.

Patterns of salt movement from drilling fluid into overlying soil were somewhat different on the Weatherby study site. Mean soil EC values in the 0 to $15-\mathrm{cm}$ increment above the drilling fluid ranged from 16.4 to $23.6 \mathrm{ds} \mathrm{m}^{-1}$ after 44 months, but differences were not significant (Table 1). Averaged over depth of burial, electrical conductivities in the 15 to $30-\mathrm{cm}$ increment increased significantly over

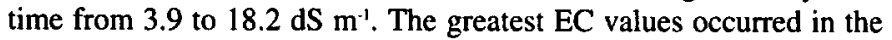
$90-$ and $150-\mathrm{cm}$ burial treatments (37.3 and $17.4 \mathrm{dS} \mathrm{m}^{1}$, respectively). Nevertheless, mean EC values of $10 \mathrm{dS} \mathrm{m}^{-1}$ in the surface $15 \mathrm{~cm}$ of the $30-\mathrm{cm}$ burial treatment would reduce seedling establishment and yield of many non-salt-tolerant plant species (U.S. Salinity Laboratory Staff 1954). The time $\mathrm{x}$ treatment interaction was significant for EC values in the 30 to $60-\mathrm{cm}$ increment. Both the $90-$ and $150-\mathrm{cm}$ burial depths exhibited significant increases in EC values from 20 to 44 months. The capillary barrier did not decrease average $\mathrm{EC}$ values in the 0 to $15-$ and 15 to $30-\mathrm{cm}$ increments. Failure of the limestone material used at this site to provide an effective barrier at the soil-drilling fluid interface was also evident after 20 months (McFarland et al. 1992a). However, the capillary barrier did limit salt movement into the 30 to $60-\mathrm{cm}$ increment and resulted in significant-
Table 2. Average exchangeable sodium percentages (ESP) at 5 increments above drilling fluid after 20 and 44 months as influenced by depth of burial.

\begin{tabular}{|c|c|c|c|c|}
\hline \multirow[b]{2}{*}{ Depth of burial } & \multicolumn{2}{|c|}{$\frac{\text { Mertz site }}{\text { Time (months) }}$} & \multicolumn{2}{|c|}{$\begin{array}{l}\text { Weatherby site } \\
\text { Time (months) }\end{array}$} \\
\hline & 20 & 44 & 20 & 44 \\
\hline$(\mathrm{cm})$ & \multicolumn{4}{|c|}{$\begin{array}{l}\text { (Increment above drilling fluid) } \ldots \ldots \ldots \\
-\end{array}$} \\
\hline 30 & 7.1 & 15.4 & 19.0 & 27.1 \\
\hline 90 & 7.1 & 14.9 & 15.9 & 33.6 \\
\hline $90+$ barrier & 1.9 & 4.9 & 7.3 & 17.9 \\
\hline 150 & 6.6 & 19.1 & 14.5 & 34.0 \\
\hline \multirow[t]{2}{*}{ Mean } & $5.7 a^{*}$ & $13.6 \mathrm{~b}$ & $14.2 \mathrm{a}^{*}$ & $28.1 b$ \\
\hline & \multicolumn{4}{|c|}{$\ldots--(15$ to $30 \mathrm{~cm})-\cdots$} \\
\hline 30 & 0.6 & $0.7 \mathrm{~A}$ & 1.6 & 13.2 \\
\hline 90 & $0.9 \mathrm{a}$ & $5.1 \mathrm{bB}$ & 2.3 & 14.6 \\
\hline $90+$ barrier & 1.1 & $0.9 \mathrm{~A}$ & 2.1 & 6.7 \\
\hline 150 & $1.8 \mathrm{a}$ & $6.9 \mathrm{bB}$ & 2.2 & 13.8 \\
\hline \multirow[t]{2}{*}{ Mean } & & & $2.1 \mathrm{a}$ & $12.1 \mathrm{~b}$ \\
\hline & \multicolumn{4}{|c|}{$\ldots \ldots-\ldots$ to $60 \mathrm{~cm}) \ldots$} \\
\hline 90 & 0.8 & 1.1 & 0.7 & 0.9 \\
\hline 90 + barrier & 1.5 & 1.2 & 1.1 & 0.8 \\
\hline 150 & 2.0 & 1.9 & 1.8 & 2.4 \\
\hline \multicolumn{5}{|c|}{$\ldots-(60$ to $75 \mathrm{~cm}) \ldots \ldots$} \\
\hline 90 & 0.6 & 0.5 & 0.6 & 0.5 \\
\hline 90 + barrier & 1.3 & 1.5 & 0.8 & 1.2 \\
\hline 150 & 1.8 & 2.1 & 2.0 & 1.8 \\
\hline \multicolumn{5}{|c|}{ 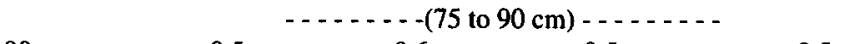 } \\
\hline 90 & 0.5 & 0.6 & 0.5 & 0.5 \\
\hline $90+$ barrier & 0.7 & 0.7 & 0.6 & 0.8 \\
\hline 150 & 1.2 & 1.0 & 1.9 & 1.2 \\
\hline
\end{tabular}

* For each location, means within a depth of burial and row followed by similar lower case letters and within an increment above drilling fluid and column followed by similar upper case letters are not significantly different by LSD ( $P \leq 0.05)$.

ly lower EC values compared to other burial depths. There was no evidence of salt movement above the 30 to $60-\mathrm{cm}$ increment on either study site.

Time and the time $\mathrm{x}$ depth of burial interaction were significant for ESP values in the 0 to 15 - and 15 to $30-\mathrm{cm}$ increments, respectively, at the Mertz site (Table 2). Averaged over depth of burial, ESP values in the 0 to $15-\mathrm{cm}$ increment increased significantly over time from 5.7 to $\mathbf{1 3 . 6}$ after $\mathbf{4 4}$ months. The capillary barrier did not significantly reduce soil exchangeable $\mathrm{Na}^{+}$in this increment. Conversely, ESP values at 15 to $30-\mathrm{cm}$ above drilling fluid in the $30-$ and $90-\mathrm{cm}+$ barrier treatments were $<1$ and were significantly less than those in the $90-$ and $150-\mathrm{cm}$ treatments (5.1 and 6.9, respectively). Significant increases in ESP values in the 90 and $150-\mathrm{cm}$ treatments over time corresponded with greater $\mathrm{EC}$ values in these treatments (Table 1 ).

Exchangeable sodium percentages in the 0 to $15-$ and 15 to $30-\mathrm{cm}$ increments on the Weatherby sitc increased significantly over time (Table 2). Depth of burial did not significantly affect ESP values, although the smallest increases were observed in the $90-\mathrm{cm}+$ barrier treatment in both increments. No significant treatment effects on ESP values were observed in soil increments $>30 \mathrm{~cm}$ above buried drilling fluids on either study site.

Depth of burial did not affect upward salt migration. However, increases in EC and ESP values in the 15 to $30-\mathrm{cm}$ increment of the shallow, 30-cm treatment tended to be less than those observed for greater depths of burial. Data collected during the first 20 months of this study showed that temporal fluctuations in soil water content were greatest for the $30-\mathrm{cm}$ burial treatment (McFarland et al. 1992a). Assuming similar patterns of water movement during the 
second evaluation period, this likely accounts for reduced EC and ESP values in the shallow burial treatment after 44 months. Since soluble salts tend to move with the wetting front, they are often temporarily leached from the surface soil zone by rainfall. These fluctuations are less substantial or absent at greater depths where more consistent patterns of salt movement and accumulation were observed. Considerable additional salt migration since the 20 -month evaluation, particularly into the 30 to $60-\mathrm{cm}$ increment above buried drilling fluid, suggests that an "equilibrium" condition may not yet have been achieved with respect to upward salt movement.

Site differences with respect to the degree of salt movement were attributed to greater effects of high salt concentrations on soil hydraulic properties, primarily as a result of differences in clay type and content. The Mertz site had a higher clay content and contained a greater percentage of expanding clays than the Weatherby site. In Na-affected soils, swelling of clay particles reduces soil pore size, and movement of clay platelets as a result of clay dispersion further blocks pores. Saturated hydraulic conductivity generally decreases as salt concentration decreases or as ESP increases. The effect is usually greatest for soils with high contents of swelling minerals and those with high clay contents (Bresler et al. 1982).

Analyses of the drilling fluids used indicated that $\mathrm{Ba}, \mathrm{Cr}, \mathrm{Cu}, \mathrm{Ni}$ and $\mathrm{Zn}$ occurred in concentrations greater than those in the native soils (McFarland et al. 1992a). Analyses of soil samples collected from the 0 to $15-\mathrm{cm}$ zone above drilling fluid 1 and 20 months after pits were covered showed no evidence of upward movement of these metals over time. Soil analyses after 44 months also showed no upward movement of these metals (data not shown). Little or no movement of these metals would be expected in alkaline, calcareous soils due to sorption and/or precipitation reactions which immobilize them in or near the waste/soil interface.

\section{Plant Growth and Chemical Composition}

Survival of fourwing saltbush transplants after 44 months ranged from 92 to $100 \%$, and depth of drilling fluid burial did not significantly affect saltbush survival. Spread and overlap of stolons of buffalograss transplants prevented measurement of individual transplant survival, but there were no indications of additional plant mortality after 44 months.

Similar to the 17-month evaluation, canopy cover of fourwing saltbush transplants 44 months after planting was significantly greater on plots with buried drilling fluids (45 to $76 \%$ ) compared to control plots (22 to $32 \%$ ) at both study sites (Table 3 ). This difference was

Table 3. Average canopy cover and biomass production of fourwing saltbush and buffalograss transplants 44 months after planting on the Mertz and Weatherby study sites as influenced by depth of drilling fluid burial.

\begin{tabular}{|c|c|c|c|c|}
\hline \multirow[b]{2}{*}{ Depth of burial } & \multicolumn{2}{|c|}{ Mertz study site } & \multicolumn{2}{|c|}{ Weatherby study site } \\
\hline & Saltbush & Buffalograss & Saltbush & Buffalograss \\
\hline \multicolumn{5}{|l|}{$(\mathrm{cm})$} \\
\hline & $\ldots \ldots$ & -Canopy c & $(\%) \ldots$ & - \\
\hline Control & $22 \mathrm{a}^{*}$ & 6 & $32 a$ & 12 \\
\hline 30 & $45 b$ & 10 & $76 \mathrm{~b}$ & 14 \\
\hline 90 & $64 c$ & 16 & $62 b$ & 24 \\
\hline $90+$ barrier & $62 c$ & 14 & $65 b$ & 23 \\
\hline \multirow[t]{2}{*}{150} & $60 c$ & 20 & $67 \mathrm{~b}$ & 24 \\
\hline & $\ldots$ & - -Biomass & $\left.h a^{-1}\right)$ & $\ldots$ \\
\hline Control & $1749 a$ & 115 & $4184 a$ & 301 \\
\hline 30 & $12822 b$ & 101 & $16464 b$ & 226 \\
\hline 90 & $17884 b c$ & 231 & $11450 \mathrm{~b}$ & 555 \\
\hline $90+$ barrier & $18826 b c$ & 381 & $13000 \mathrm{~b}$ & 345 \\
\hline 150 & $21501 c$ & 372 & $12433 b$ & 278 \\
\hline
\end{tabular}

* Means within a parameter and column followed by similar lower case letters are not significantly different according to Duncan's new multiple range test $(P \leq 0.05)$.
Table 4. Concentrations of $\mathrm{Na}, \mathrm{K}, \mathrm{Ca}$ and $\mathrm{Mg}$ in fourwing saltbush and buffalograss tissue 44 months after planting on the Mertz and Weatherby study sites as influenced by depth of drilling fluid burial.

\begin{tabular}{|c|c|c|c|c|c|c|}
\hline \multirow[b]{3}{*}{$\begin{array}{l}\text { Depth of } \\
\text { burial }\end{array}$} & \multicolumn{2}{|c|}{ Mertz study site } & \multirow[b]{3}{*}{$\begin{array}{c}\text { Buffalo- } \\
\text { grass }\end{array}$} & \multicolumn{3}{|c|}{ Weatherby study site } \\
\hline & \multicolumn{2}{|c|}{ Fourwing saltbush } & & \multicolumn{3}{|c|}{ Fourwing saltbush } \\
\hline & Leaf & Stem & & Leaf & Stem & $\begin{array}{c}\text { Buffalo- } \\
\text { grass }\end{array}$ \\
\hline$(\mathrm{cm})$ & \multicolumn{6}{|c|}{ 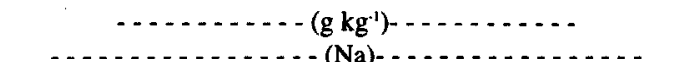 } \\
\hline Control & 0.18 & $0.04 \mathrm{~b} *$ & 0.03 & $0.11 \mathrm{ab}$ & 0.03 & $0.03 a$ \\
\hline 30 & 0.12 & $0.02 \mathrm{a}$ & 0.05 & $0.14 \mathrm{~b}$ & 0.04 & $0.07 \mathrm{~b}$ \\
\hline 90 & 0.11 & $0.02 \mathrm{a}$ & 0.04 & $0.09 \mathrm{a}$ & 0.03 & $0.05 \mathrm{ab}$ \\
\hline 90 + barrier & 0.10 & $0.02 \mathrm{a}$ & 0.04 & $0.10 \mathrm{ab}$ & 0.03 & $0.05 \mathrm{ab}$ \\
\hline 150 & 0.10 & $0.02 a$ & 0.04 & $0.08 a$ & 0.03 & $0.04 a$ \\
\hline Control & $44.6 a^{--}$ & 12.8 & 3.5 & $45.6 \mathrm{a}$ & 16.3 & 4.4 \\
\hline 30 & $52.3 \mathrm{ab}$ & 12.5 & 3.7 & $63.7 \mathrm{~b}$ & 16.1 & 3.9 \\
\hline 90 & $61.6 \mathrm{bc}$ & 13.7 & 3.7 & $60.5 b$ & 15.6 & 4.3 \\
\hline $90+$ barrier & $60.3 \mathrm{bc}$ & 13.8 & 3.7 & $59.2 \mathrm{~b}$ & 18.1 & 4.7 \\
\hline \multirow[t]{2}{*}{150} & $63.7 \mathrm{c}$ & 12.6 & 4.3 & $61.8 \mathrm{~b}$ & 16.6 & 4.4 \\
\hline & \multicolumn{6}{|c|}{. } \\
\hline Control & $36.9 \mathrm{~b}$ & 10.2 & 7.7 & $35.3 b$ & $8.4 c$ & 8.8 \\
\hline 30 & $23.6 \mathrm{a}$ & 5.7 & 8.3 & $21.4 \mathrm{a}$ & $5.2 \mathrm{a}$ & 14.0 \\
\hline 90 & $22.0 \mathrm{a}$ & 5.3 & 8.5 & $21.2 \mathrm{a}$ & 5.3ab & 11.6 \\
\hline $90+b$ & $19.5 \mathrm{a}$ & 5.3 & 8.5 & $24.7 \mathrm{a}$ & $6.6 \mathrm{~b}$ & 11.5 \\
\hline \multirow[t]{2}{*}{150} & $22.5 a$ & 4.8 & 7.7 & $20.3 \mathrm{a}$ & $5.3 \mathrm{ab}$ & 13.2 \\
\hline & \multirow{2}{*}{\multicolumn{2}{|c|}{$66^{--}$}} & \multicolumn{2}{|c|}{ - - (Mg) } & & -1 \\
\hline Cont & & & 1.3 & $9.9 \mathrm{c}$ & 2.5 & 1.1 \\
\hline 30 & 7.1 & 1.7 & 1.3 & $7.5 \mathrm{a}$ & 2.0 & 1.6 \\
\hline 90 & 6.6 & 1.7 & 1.4 & $8.6 \mathrm{ab}$ & 2.1 & 1.3 \\
\hline $90+$ barrier & 6.1 & 1.7 & 1.1 & $9.0 \mathrm{bc}$ & 2.4 & 1.4 \\
\hline 150 & 6.4 & 1.6 & 1.2 & $10.0 \mathrm{c}$ & 2.3 & 1.5 \\
\hline
\end{tabular}

* Means within an element and column followed by similar lower case letters are not significantly different according to Duncan's new multiple range test $(P \leq 0.05)$.

attributed to the tillage effect associated with pit construction, which was also observed to improve initial plant growth and establishment (McFarland et al. 1992b). However, average canopy cover of fourwing saltbush on the $30-\mathrm{cm}$ treatment on the Mertz site was significantly less than on other treatments with buried drilling fluid. A similar trend was observed for buffalograss on both sites, although differences were not significant. Fourwing saltbush canopy cover had increased by 6 to $20 \%$ during the preceding 2 years, while buffalograss canopy cover had decreased on most plots by 3 to $11 \%$. Regression equations for estimating total aboveground biomass of fourwing saltbush were: $\log W=-5.024+0.918\left[\log \left(4 \pi r^{3} / 3\right)\right]$ for the Mertz site, and $\log W=-7.660+1.063\left[\log \left(\pi r^{2} h\right)\right]$ for the Weatherby site, where $r$ is the average plant canopy radius in $\mathrm{cm}, \mathrm{h}$ is plant height in $\mathrm{cm}$, and oven-dry weight $(\mathrm{W})$ is expressed in grams. These equations accounted for 89 and $97 \%$ of the variability in aboveground biomass for fourwing saltbush at the Mertz and Weatherby sites, respectively.

Fourwing saltbush biomass production was significantly greater on treated plots $\left(11,450\right.$ to $\left.21,501 \mathrm{~kg} \mathrm{ha}^{-1}\right)$ compared to control plots $\left(1,749\right.$ to $\left.4,184 \mathrm{~kg} \mathrm{ha}^{-1}\right)$ after 44 months (Table 3 ). This corresponded with results observed at 17 months, although saltbush yields had increased by 561 to $14,261 \mathrm{~kg} \mathrm{ha}^{-1}$, and was similarly attributed to the tillage effect caused by pit construction. Yields of fourwing saltbush at the Mertz site on plots with drilling fluids buried $30 \mathrm{~cm}$ were significantly less than those on the $150-\mathrm{cm}$ burial treatment. This response was not observed on the Weatherby site, most likely because of differences in soil type and clay content. The greater percentage of expanding clays at the Mertz site facilitated increased clay dispersion. Subsequent reductions in oxygen diffusion and infiltration of water may have been primary factors in limiting plant growth 
on the Mertz site. This would explain the observed differences in plant growth even though root zone salinities in the $30-\mathrm{cm}$ depth of burial treatment were greater on the Weatherby site.

Buffalograss yields were not affected by depth of drilling fluid burial (Table 3). However, biomass production in the fourth growing season was 12 to $75 \%$ less than that after 2 growing seasons (McFarland et al. 1992b). In contrast to fourwing saltbush, lower yields of buffalograss were attributed to the combined effects of shallow rooting of this species and below average rainfall received during the 1989 growing season.

Sodium concentrations in buffalograss growing on the $30-\mathrm{cm}$ treatment on the Weatherby site were significantly greater than those in buffalograss growing on control or $150-\mathrm{cm}$ burial treatments (Table 4). Saltbush leaves from $30-\mathrm{cm}$ burial treatments on the Weatherby site also contained more $\mathrm{Na}$ than those from plots with drilling fluids buried 90 or $150 \mathrm{~cm}$. In contrast, there was no evidence of elevated $\mathrm{Na}$ concentrations in either species on plots with buried drilling fluid at the Mertz site. These site differences were likely attributable to greater upward salt migration at the Wcatherby site (Tables 1 and 2). The elevated Na concentrations in buffalograss at the Weatherby site were similar in magnitude to those observed 17 months after planting (McFarland et al. 1992b). Thus, although additional upward salt movement occurred after 44 months, accumulations in plant tissue remained relatively constant.

Table 5. Concentrations of $\mathrm{Ba}, \mathrm{Cr}, \mathrm{Cu}, \mathrm{Ni}$ and $\mathrm{Zn}$ in fourwing saltbush and buffalograss tissue 44 months after planting on the Mertz and Weatherby study sites as influenced by depth of drilling fluid burial.

\begin{tabular}{|c|c|c|c|c|c|c|}
\hline \multirow[b]{3}{*}{$\begin{array}{l}\text { Depth of } \\
\text { burial }\end{array}$} & \multicolumn{2}{|c|}{ Mertz study site } & & \multicolumn{3}{|c|}{ Weatherby study site } \\
\hline & \multicolumn{2}{|c|}{ Fourwing saltbush } & \multirow[b]{2}{*}{$\begin{array}{c}\text { Buffalo- } \\
\text { grass }\end{array}$} & \multicolumn{2}{|c|}{ Fourwing saltbush } & \multirow[b]{2}{*}{$\begin{array}{c}\text { Buffalo- } \\
\text { grass }\end{array}$} \\
\hline & Leaf & Stem & & Leaf & Stem & \\
\hline$(\mathrm{cm})$ & \multirow{2}{*}{\multicolumn{6}{|c|}{$\ldots\left(\right.$ mg kg $\left.{ }^{1}\right) \ldots$}} \\
\hline & & & & & & \\
\hline Control & 74.9 & $38.6 b^{*}$ & 46.5 & $55.2 b$ & 20.3 & 45.0 \\
\hline 30 & 47.8 & $18.0 \mathbf{a}$ & 39.5 & $42.5 \mathrm{ab}$ & 15.8 & 49.2 \\
\hline 90 & 50.0 & 23.1a & 44.3 & $48.2 b$ & 20.9 & 50.5 \\
\hline 90 + barrier & 43.7 & $19.6 \mathrm{a}$ & 41.7 & $53.1 \mathrm{~b}$ & 21.5 & 52.6 \\
\hline \multirow[t]{2}{*}{150} & 48.9 & $19.7 \mathrm{a}$ & 39.1 & $32.7 \mathrm{a}$ & 13.7 & 52.4 \\
\hline & \multicolumn{6}{|c|}{$\ldots \ldots-\ldots-1 \mathrm{Cr})-\ldots \ldots$} \\
\hline Control & 6.1 & 3.6 & 2.0 & 6.0 & 4.2 & 4.1 \\
\hline 30 & 5.7 & 3.1 & 1.9 & 4.3 & 1.7 & 7.1 \\
\hline 90 & 5.1 & 3.2 & 1.7 & 7.4 & 3.8 & 6.6 \\
\hline 90 + barrier & 6.5 & 3.0 & 1.6 & 6.3 & 4.2 & 4.9 \\
\hline \multirow[t]{2}{*}{150} & 5.4 & 2.8 & 2.1 & 4.2 & 2.8 & 5.2 \\
\hline & \multicolumn{6}{|c|}{$\ldots \ldots(\mathrm{Cu}) \ldots \ldots \ldots$} \\
\hline 30 & 12.1 & $5.8 \mathrm{~b}$ & 6.1 & 13.5 & 6.4 & 7.3 \\
\hline 90 & 12.8 & $5.7 \mathrm{~b}$ & 5.2 & 13.9 & 6.0 & 7.3 \\
\hline 90 + barrier & 12.6 & $5.9 \mathrm{~b}$ & 5.6 & 11.1 & 5.7 & 7.8 \\
\hline \multirow[t]{2}{*}{150} & 13.7 & $5.8 \mathrm{~b}$ & 5.8 & 13.2 & 5.4 & 7.2 \\
\hline & \multicolumn{6}{|c|}{ 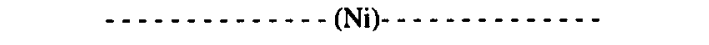 } \\
\hline \multicolumn{7}{|l|}{ Contro } \\
\hline & 5.1 & 3.4 & 1.8 & 8.3 & 4.7 & 1.9 \\
\hline 30 & 3.2 & 3.8 & 1.4 & 8.0 & 2.2 & 2.2 \\
\hline 90 & 4.1 & 2.9 & 1.0 & 8.0 & 5.5 & 1.6 \\
\hline 90 + barrier & 5.8 & 1.5 & 1.7 & 5.9 & 4.6 & 1.9 \\
\hline 150 & 5.0 & 3.9 & 1.8 & 8.6 & 4.8 & 1.7 \\
\hline \multicolumn{7}{|c|}{$\ldots \ldots \ldots$} \\
\hline Control & 18.4 & 8.8 & 51.3 & 17.9 & $9.6 \mathrm{a}$ & 50.2 \\
\hline 30 & 38.9 & 17.4 & 35.7 & 24.7 & $14.0 \mathrm{~b}$ & 44.1 \\
\hline 90 & 37.8 & 16.0 & 37.9 & 28.4 & $14.2 \mathrm{~b}$ & 55.9 \\
\hline $90+$ barrier & 41.0 & 18.9 & 35.5 & 32.7 & $14.9 b$ & 54.1 \\
\hline 150 & 41.5 & 17.6 & 37.3 & 37.4 & $13.9 \mathrm{~b}$ & 49.3 \\
\hline
\end{tabular}

*Mean within an element and column followed by similar lower case letters are not sig nificantly different according to Duncan's new multiple range test $(P \leq 0.05)$.
Concentrations of $\mathrm{K}$ in fourwing saltbush leaves growing on control plots at both locations were significantly less than those in plants growing on most plots with buried drilling fluids (Table 4). In contrast, concentrations of $\mathrm{Ca}$ in fourwing saltbush leaves growing on control plots at both locations, and in saltbush stems growing on control plots at the Weatherby site were significantly greater than those in plants growing on plots with buried drilling wastes. Since these results tended to be consistent for treated plots versus control plots, they were attributed to residual effects of pit construction on plant growth (tillage effect) and nutrient availability (soil profile mixing), rather than to the direct effect of buried drilling fluids. Concentrations of $\mathrm{Mg}$ in saltbush leaves on control plots were greater than those on plots with drilling fluids buried 30 and $90 \mathrm{~cm}$ deep on the Weatherby lease.

Concentrations of $\mathrm{Na}$ in buffalograss and fourwing saltbush tissues in this study $\left(0.02-0.18 \mathrm{~g} \mathrm{~kg}^{-1}\right)$ were less than the dietary requirements for $\mathrm{Na}$ in livestock $\left(\sim 2 \mathrm{~g} \mathrm{~kg}^{-1}\right)$, and thus would pose no potential toxicity problem (National Research Council 1980). Concentrations of $\mathrm{K}, \mathrm{Ca}$, and $\mathrm{Mg}$ in buffalograss and saltbush stems were below the maximum tolerable dietary levels for livestock. In contrast, fourwing saltbush leaves grown on control plots and most plots with buried drilling fluids contained concentrations of $\mathrm{K}, \mathrm{Ca}$, and $\mathrm{Mg}$ greater than maximum tolerable dietary levels for livestock (K $30 \mathrm{~g} \mathrm{~kg}^{-1}$; Ca $20 \mathrm{~g} \mathrm{~kg}^{-1}$; $\mathrm{Mg} 5 \mathrm{~g} \mathrm{~kg}^{-1}$ ) (National Research Council 1980). Other researchers have reported very high concentrations of $\mathrm{Na}\left(0.9-32 \mathrm{~kg}^{-1}\right), \mathrm{K}\left(21-69 \mathrm{~g} \mathrm{~kg}^{-1}\right), \mathrm{Ca}\left(7-13 \mathrm{~g} \mathrm{~kg}^{-1}\right)$, and $\mathrm{Mg}(6-9 \mathrm{~g}$ $\mathrm{kg}^{-1}$ ) in fourwing saltbush (Smit and Jacobs 1978, Richardson 1982, Khalil et al. 1986). Our data suggest that the population of fourwing saltbush used in this study was a low-sodium biotype that excludes $\mathrm{Na}$ but absorbs large amounts of $\mathrm{K}$ (Richardson 1982). The high $\mathrm{K}$, $\mathrm{Ca}$, and $\mathrm{Mg}$ concentrations in fourwing saltbush leaves would not be expected to cause toxicity problems under normal range conditions because the shrub is not highly palatable and usually comprises only a small proportion of the total diet of livestock.

There was no evidence of increased absorption of $\mathrm{Ba}, \mathrm{Cr}$, or $\mathrm{Ni}$ by fourwing saltbush or buffalograss on plots with buried drilling fluids compared to control plots, and only limited evidence of increased uptake of $\mathrm{Cu}$ and $\mathrm{Zn}$ (Table 5). Concentrations of $\mathrm{Cu}$ (Mertz site) and $\mathrm{Zn}$ (Weatherby site) were greater in saltbush stems on plots with buried drilling fluids compared to the controls, as was observed 20 months after the drilling fluids were buried (McFarland et al. 1992b). However, the absence of a significant depth of burial effect suggests that differences were due to the influence of soil disturbance on plant utilization of native soil $\mathrm{Cu}$ and $\mathrm{Zn}$, rather than uptake of metals contained in the drilling fluids. In contrast, total $\mathrm{Ba}$ concentrations in fourwing saltbush leaves were significantly lower on most plots with buried drilling fluids compared to control plots (Table 5). Concentrations of $\mathrm{Ba}$ in buffalograss and saltbush tissues were within the range reported for other plant species (Nielsen 1986). Levels of soluble Ba should not exceed $20 \mathrm{mg} \mathrm{kg}^{-1}$ in livestock diets, but much of the Ba present in plant material is not biologically available and is of little concern (National Research Council 1980). Concentrations of $\mathrm{Cr}$, $\mathrm{Cu}, \mathrm{Ni}$, and $\mathrm{Zn}$ in buffalograss and fourwing saltbush tissues were well below the maximum tolerable dietary levels for livestock $(\mathrm{Cr}$ $1,000-3,000 \mathrm{mg} \mathrm{kg}^{-1} ; \mathrm{Cu}>25 \mathrm{mg} \mathrm{kg}^{-1}$ for adult sheep, $>100 \mathrm{mg} \mathrm{kg}^{-1}$ for adult cattle; Ni $50 \mathrm{mg} \mathrm{kg}^{-1}$; Zn $300-500 \mathrm{mg} \mathrm{kg}^{-1}$ ) (National Research Council 1980).

\section{Conclusions}

Burial of spent drilling fluids in arid and semiarid environments is a viable alternative to the conventional method of surface disposal. 
Soluble salt migration as much as 30 to $60 \mathrm{~cm}$ into soil overlying drilling fluid had occurred after 44 months. However, adverse effects on plant growth were observed only with shallow, $30-\mathrm{cm}$ burial and were restricted to soils with higher clay contents. Increases in plant tissue salt concentrations indicated that uptake of drilling fluid constituents may occur with shallow burial, but heavy metals will not be available to plants under the conditions reported here. Selectiveplacement burial of drilling fluids reduces the rate and extent of soil contamination on drilling sites, and should facilitate natural or artificial revegetation.

\section{Literature Cited}

Blum, E.L. 1977. Soil survey of Sterling County, Texas. USDA Soil Conserv. Serv., U.S. Govt. Printing Office, Washington, D.C.

Bresler, E., B.L. McNeal, and D.L. Carter. 1982. Saline and Sodic Soils. Springer-Verlag, N.Y.

Canfield, R.H. 1941. Application of the line interception method in sampling range vegetation. J. Forest. 39:388-394.

Gomez, K.A., and A.A. Gomez. 1984. Statistical procedures for agricultural research. Second edition. John Wiley \& Sons, N.Y.

Khalil, J.K., W.N. Sawaya, and S.Z. Hyder. 1986. Nutrient composition of Atriplex leaves grown in Saudi Arabia. J. Range Manage. 39:104-107.

McFarland, M.L., D.N. Ueckert, and S. Hartmann. 1987. Revegetation of oil well reserve pits in west Texas. J. Range Manage. 40:122-127.
McFarland, M.L., D.N. Ueckert, F.M. Hons, and S. Hartmann. 1992a. Selective-placement burial of drilling fluids: I. Effects on soil chemical properties. J. Environ. Qual. 21:135-139.

McFarland, M.L., D.N. Ueckert, F.M. Hons, and S. Hartmann. 1992b. Selective-placement burial of drilling fluids: II. Effects on buffalograss and fourwing saltbush. J. Environ. Qual, 21:140-144.

National Research Council 1980. Mineral tolerances of domestic animals. National Academy of Sciences. Washington, D.C.

Nelson, D.W., S.L. Liu, and L.E. Sommers. 1984. Extractability and plant uptake of trace elements from drilling fluids. J. Environ. Qual. 13:562-566.

Nielsen, F.H. 1986. Other elements: $\mathrm{Sb}, \mathrm{Ba}, \mathrm{B}, \mathrm{Br}, \mathrm{Cs}, \mathrm{Ge}, \mathrm{Rb}, \mathrm{Ag}, \mathrm{Sr}, \mathrm{Sn}$, $\mathrm{Ti}, \mathrm{Zr}, \mathrm{Be}, \mathrm{Bi}, \mathrm{Ga}, \mathrm{Au}, \mathrm{In}, \mathrm{Nb}, \mathrm{Sc}, \mathrm{Te}, \mathrm{Tl}, \mathrm{W}, \mathrm{p}$. 415-463. In: W. Mertz (ed.), Trace elements in human and animal nutrition - Fifth Edition, Vol. 2. Academic Press, Inc., Orlando, Fla.

Peterson, J.L., D.N. Ueckert, R.L. Potter, and J.E. Huston. 1987. Ecotypic variation in selected fourwing saltbush populations in western Texas. J. Range Manage. 40:361-366.

Richardson, S.G. 1982. High and low sodium biotypes of fourwing saltbush: their response to sodium and potassium in retorted oil shale. J. Range Manage. 35:795-797.

Smit, C.J. and G.A. Jacobs. 1978. Skeikundige samestelling van vier Atriplex-species. Agroanimalia 10:1-5.

Soil Survey Staff. 1972. Soil survey laboratory methods and procedures for collecting soil samples. Soil survey investigations report no. 1. USDA, U.S. Gov. Printing Office, Washington, D.C.

U.S. Salinity Laboratory Staff. 1954. Diagnosis and improvement of saline and alkali soil. USDA Handb. No. 60, U.S. Govt. Printing Office. Washington D.C.

Wiedenfeld, C.C. 1980. Soil survey of Schleicher County, Texas. U.S.D.A. Soil Conserv. Service. U.S. Government Printing Office, Washington, D.C. 